\title{
Legal Capacities of the Dayton Constitution in the Process of Accession of Bosnia and Herzegovina to European Union
}

\author{
Zlatan Begić ${ }^{1}$ \\ ${ }^{1}$ Faculty of Law, University of Tuzla, Bosnia and Herzegovina \\ Correspondence: Zlatan Begić, Faculty of Law, University of Tuzla, Bosnia and Herzegovina. E-mail: \\ zlatan.begic@untz.ba
}

Received: October 8, 2015 Accepted: November 18, 2015 Online Published: February 28, 2016

doi:10.5539/jpl.v9n1p11 URL: http://dx.doi.org/10.5539/jpl.v9n1p11

\begin{abstract}
The central part of this paper is concerned with the possibilities of the Dayton Constitution in the process of accession of Bosnia and Herzegovina to European Union. At the first place, this paper contains an analysis of the legal power of the general principles of international law in the constitutional system of Bosnia and Herzegovina, in particular, the pacta sunt servanda principle which has significant importance, in legal sense, for implementation obligations deriving from the international agreements related to European integration. In this regard, it should be emphasized that Article III/3b of the $\mathrm{BH}$ Constitution implicitly refers to the obligatory implementation of the aforementioned principles. In terms of commitments deriving from the European integration process, this paper also includes an analysis of the other constitutional possibilities for harmonization entity legislation and establishment integrated state frame and functional unified single market on the territory of Bosnia and Herzegovina.
\end{abstract}

Keywords: European integrations, constitution, reform, constitutional rights, Dayton Peace Agreement

\section{Introduction}

The Constitution of Bosnia and Herzegovina (hereinafter: $\mathrm{BH}$ ) is a part of the peace agreement known as Dayton Peace Agreement (hereinafter: DPA) that stopped the war. In consequence, a complex system of state organization has been established by the DPA, along with complicated decision-making procedures that include a variety of blockade mechanisms. However, it is clear that the primary goal of this agreement was not comprised in establishment of the functional system of state institutions which would have possessed sufficient level of capacity to answer in appropriate manner to demands of citizens, and contemporary integration process in Europe. Besides, the Dayton Constitution as a part of the DPA consists a number of provisions which enable integration of the legal system and implementation of the obligations from European integration process.

The process of European integration in the legal-technical sense involves access of BH to the agreements of international character defining commitments from European integrations and the adoption of appropriate laws necessary for their implementation. In this way the $\mathrm{BH}$ is obliged under international law, but the violation of such obligations, in accordance with constitutional arrangements and the practice of the Constitutional Court, would also constitute a violation of its Constitution. This fact arising from the Article III/3b of this Constitution which stipulates that the general principles of international law shall be an integral part of the legal order of $\mathrm{BH}$ and the entities. For the purpose of this paper, the principle pacta sunt servanda, besides the others, has special importance. This principle is related to fulfilling of accepted international commitments of BH in good faith. In this regard, the pacta sunt servanda principle as a part of the inner BH legal order is very significant from the standpoint of fulfillment obligations deriving from the process of EU integrations. Thus, this principle constitute a default value, which the state Constitution itself sets and protects, for the holders of legislative, judicial and executive functions at all levels of government. Compliance of regulations, either material or formal, with this principle of international law, therefore, is a constitutional obligation for the holders of authority in $\mathrm{BH}$ and the entities. Insofar the breach of the principle pacta sunt servanda in domain of the execution of commitments stipulated by the agreements defining the $\mathrm{BH}$ path in the process of European integration would also constitute a violation of the Constitution of $\mathrm{BH}$, which will be discussed in the following text. 


\section{General Remarks}

BH is a complex state, consisted of two entities - the Republic of Srpska (hereinafter: RS) and the Federation of Bosnia and Herzegovina (hereinafter: Federation of $\mathrm{BH}$ ), in which there is division of jurisdiction between the state and entity levels. The RS is unitary organized entity while the Federation of BH is organized on federal principle. This entity consists of ten federal units - cantons and there is also division of the competencies between Federation and cantons stipulated by the Constitution of the Federation of BH (see more: Begić, Idrizović, 2015: 81-87; Subašić, 2015: 68).

Significant number of the competencies relevant to the process of European integration is the responsibility of the entities as well as the cantons in the Federation of BH. Because of lack of coordination between state and entity level as well as Federation and cantons in exercising of their competencies, implementation of the commitments deriving from EU integration process and defined by the international agreements have been stopped. Because of that, there were a few efforts for constitutional reform (see more: Filandra, 2014: 20-22; Cipek, 2014: 4-5). However, the Dayton Constitution consists solutions which enable exercising of competencies belonging to all levels of the state organization in a way which could ensure efficient execution of the international commitments related to European integration process. Unfortunately, these constitutional possibilities were not used sufficiently in the previous period mostly because of the political reasons and misunderstandings (see more: Basta, 2015: 178-182). Since the Constitution of BH refers to the general principles of international law, including the principle of pacta sunt servanda, those competencies must be carried out simultaneously in a manner that ensures consistent execution of the assumed international obligations, which also will be discussed in the following text.

\section{General Principles of International Law in the BH Constitution}

Under the general principles of international law, we could include certain rules of higher order, which itself represent a specific sui generis source of law and which must be taken into account, either in resolving certain disputes, or in the standardization of certain areas.

According to J. Pauwelyn,"“a]lthough certain authors, in particular in Soviet doctrine, refused to accept 'general principles of law' as a distinct source of international law in recent times at least one point of convergence seems to have emerged, namely that general principles of law constitute a genuine source of positive international law" (Pauwelyn, 2003: 124-125).

However, as C. G. Weeramantry observes, "[w]e cannot permit ourselves to forget that some of the most abiding and notable rules of international law, be the pacta sunt servanda itself, and the requirement of good faith or the obligations attendant on fiduciary relationships such as mandate or trusteeship, derived their origin and continuing inspiration from customary international law" (Weeramantry, 2004: 230-231).

Article III/3b of the BH Constitution states that "[ $\mathrm{t}]$ he general principles of international law shall be an integral part of the law of BH and the entities." Violation of these principles which, beyond any doubt, are the principles of international law of general nature would, in most cases, produce a responsibility of violator state under international law (see more: Degan, 2009: 517, 521-522; Degan, 2000: 70-76, 233-240; Henderson, 2010: 72; Weinert, 2007: 101-102; Shaw, 2003: 103-104; Pulkowski, 2008: 51,60; Besson, 2010: 163, 165; Shea, 1955: 179; Guzman, 2008: 204-209; Miéville, 2005: 72, 166-167; Klabbers, 2009: 149-150). However, the issue of key importance for $\mathrm{BH}$ is: whether it would eventual breach of the general principles of international law, especially the pacta sunt servanda principle in regard to state responsibility under international law for implementation of international obligations, at the same time constitute a violation of the Constitution of BH, i.e., its article III/3b? When it comes to general principles of international law it is obvious that the BH Constitution follows the concept of monistic theories / methods of adoption. This Constitution thereby is not determined by legal effect of these principles in the overall legal order of BH. (see: Begić, 2012: 61-62)

In a similar way, but more accurately, in terms of position of the general rules of international character within the legal system of Germany, Article 25 of the Basic Law of the Federal Republic of Germany stipulates: "The general rules of international law are an integral part of federal law. They have priority over the laws and directly produce the rights and obligations of residents from the area of the state. " By this act, as can be seen from the above cited norms of the Basic Law, suggested as part of inner law as a part of the legal system of Germany, the general rules of international law, which is much broader formulation in relation to the formulation of article $\mathrm{III} / 3 \mathrm{~b}$ of the $\mathrm{BH}$ Constitution, since the general principles of international law, which the BH Constitution refers to, represent only a fraction of the total system of the general norms / rules of international law. However, with Article VI/3 c of the Constitution of BH this application was extended to other general rules of international law that have no character of principles. To eliminate the possibility of far too wide interpretation of cited provision of Article 25 Basic Law of Germany, Article 100 / 2 of this act, much like the Constitution of BH, prescribes the 
jurisdiction of the Federal Constitutional Court for establishing, in case of doubt, whether a general rule of international law is part of Federal law and whether it, as such produces valid rights and obligations. However, Article VI/3c of the Constitution of $\mathrm{BH}$ prescribes the jurisdiction of the Constitutional Court of $\mathrm{BH}$ in a way that this Court has jurisdiction, inter alia, "...the existence of or the scope of a general rule of public international law pertinent to the court's decision. "This confirmed the monistic conception that the domestic courts, in this case the Constitutional Court of $\mathrm{BH}$, apply the rules of international law and, in addition to general principles of international law, as relevant sources of law, and that in the constitutional system of $\mathrm{BH}$ other rules of international law that have general character are confirmed (see: Begić, 2012: 61).

Similar provisions can be found in the Italian Constitution from 1947 (Article 10 / 1), Constitution of Greece from 1975 (Article 28 / 1), the Austrian Constitution from 1955 (Article 9), etc. The French Constitution also stipulates: "The French Republic faithful to its traditions, will be harmonized with the rules of public international law." Courts in France apply the rules of customary international law grounding its decisions on the quoted constitutional norm (see: Degan, 2000: 23).

In this regard, one can conclude that the general principles of international law, in accordance with Article III/3b and $\mathrm{VI} / 3 \mathrm{c}$ and the concept of constitutional arrangements, undoubtedly constitute a default value, which the state constitution itself sets and protects, for the holders of legislative, judicial and executive functions at all levels of government (For other competencies of the Constitutional Court deriving from the Art. VI/3c see: Simović, N. M., Simović M. 2014: 65). Compliance of regulations, either material or formal, with the general principles of international law, therefore, is a constitutional obligation for the holders of authority in $\mathrm{BH}$ and the entities. Insofar the breach of these principles would also constitute a violation of the Constitution of BH.

This standpoint was confirmed by the practice of the Constitutional Court of BH. Considering the demand for protection of constitutionality in the case U-5/09 in relation to the Act on the Protection of Domestic Production in the Framework of the CEFTA ("Official Gazette of BH" No. 49/09) the Constitutional Court of BH ultimately concluded that adoption of the controversial legislation violated Article III/3b of the BH Constitution. The Court went further to conclude that Article III/3b of the Constitution of BH is violated in any situation where domestic law is inconsistent with the provisions of general rules of international law pacta sunt servanda according to which "Every agreement in force binds member states and they need to execute it in good faith, "as well as when it is not in accordance with the provisions of international treaties to which BH acceded.

\section{Pacta Sunt Servanda in the Context of the Reform Processes}

In the case of $\mathrm{BH}$ various legal situations are possible when fulfilling the obligations specified by the ratified international contracts in the context of the application of the pacta sunt servanda principle. The first involves the need for intervention into BH Constitution provisions due to the obligations specified by the ratified international agreements. It includes the circumstances under which the obligations accessed or ratified by $\mathrm{BH}$ collide directly with the BH Constitution provisions. For example, BH ratified the European Convention on Human Rights (ECHR) and its Protocol 12. Until the ratification act, the ECHR was applied to the BH territory only partially by virtue of its Constitution, since Article II/2 of the BH Constitution refers to this Convention. This constitutional act created the framework for a partial implementation of ECHR provisions in a scope compatible with other BH Constitution provisions. However, by ratifying the Convention, the state of $\mathrm{BH}$ was obliged under international law to implement ECHR provisions and provisions of its Protocol 12 in a proper way. Therefore, the provision of Article III/3b of the $\mathrm{BH}$ Constitution, which refers to the pacta sunt servanda principle of the international law, was "activated" by the act of ratification (see more: Begić, 2012: 66-68; Ademović, Marko, Marković, 2012: 19-20).

This principle declares that the obligations specified by the ECHR and its ratified Protocols must be fulfilled according not only to international law but also to the BH Constitution. It is therefore indisputable that every law, while perhaps contrary to the ECHR, is at the same time in collision with the BH Constitution according to the aforementioned Article III/3b. However, the key issue lies in the disproportion of certain parts of the $\mathrm{BH}$ Constitution and the obligations set out by the ECHR.

In this respect, obligations from international agreements that are contrary to the $\mathrm{BH}$ Constitution provisions must not be ignored. Although the aforementioned Convention and other important instruments have become part of the BH legal system due to the DPA's entry into force, the Convention's provisions can be considered as pure declarations in their reference to the certain rights they guarantee, primarily the citizens' passive voting right. Although the BH Constitution refers to the most important international legal instruments that protect these 
rights, ${ }^{1}$ it also provides the structure and procedures for electing members of the Presidency, and House of Peoples of the Parliamentary Assembly of BH that are not compatible with the mentioned international acts since this Constitution provides that only citizens who belong to the constituent peoples (Bosniacs, Serbs and Croats) have passive voting right to be candidate for this positions (see more: Vanjek, 2014: 15-16). ${ }^{2}$

Therefore, it can be argued that the BH Constitution's entry into force initiated prerequisites for the partial implementation of the international legal instrument provisions for the protection of human rights and freedoms referred to by this act, primarily of the ECHR, only as far as those provisions were compatible to other provisions of the BH Constitution. As such, the BH Constitution states that the ECHR has priority over BH's laws, but not over the Constitution itself (Article II/2 of the BH Constitution). Although the Constitution has not defined the legal position/force of other international instruments for the protection of human rights and freedoms consisted in the Annex 1 of this Constitution that treat citizens' political rights, the analogy indicates that other international legal instruments have the same legal power as the ECHR - a legal effect higher than the law but lower than the Constitution. It is clear that according to international law, such a partial implementation of the international agreements is unacceptable, especially in the case of the international instruments for the protection of human rights and freedoms, provided that the state has not formulated a reservation on certain provisions of the contract and under the assumption that such an act is permitted by the contract (see more: Trnka, 2006: 118-120; Begić, 2012: 68-69).

However, the effect of the aforementioned international instruments for the protection of human rights and freedoms when the state of $\mathrm{BH}$ commits to its implementation under international law by the act of ratification is completely different from when the provisions of these instruments are legally effective by virtue of the Constitution itself. On the provision of Article III/3b of the BH Constitution and the pacta sunt servanda general principle of the international law to which this article refers, the state's commitments by international law, including the act of ratifying such a contract by the authorized institutions, should include the harmonization of not only the legislature but also the BH Constitution along with the norms included in such an act. The act of ratification, which represents the legal act by which the state expresses its consent to fulfil the obligations specified in the international agreement, should in this case function by the lex posterior derogat legi priori principle. This principle, in relation to the pacta sunt servanda principle referred to by Article III/3b of the Constitution, implies the obligation to harmonize the entire legal system of the state, including the Constitution itself, with the obligations from the ratified international agreements (see: Begić, 2015: 169-171).

This stand point was confirmed by the practice of the Constitutional Court of BH. Considering the demand for constitutionality protection in case U-5/09 related to the Act on the Protection of Domestic Production in the Framework of the CEFTA (Central European Free Trade Agreement), the Constitutional Court of BH ultimately concluded that adopting the controversial legislation violated Article III/3b of the $\mathrm{BH}$ Constitution. The Court further concluded that Article III/3b of the $\mathrm{BH}$ Constitution is violated in any situation where domestic law is inconsistent with the provision of the general principles of international law - pacta sunt servanda.

It should be emphasized stand point of the European Court of Human Rights in Strasbourg in the Sejdić-Finci case regarding violation passive voting rights of the national minorities in $\mathrm{BH}$ guaranteed by the ECHR. Dervo Sejdić and Jacob Finci submitted an application (no. 27996/06 and 34836/06), on 3 July and 18 August 2006 against the $\mathrm{BH}$ for limiting their passive voting rights in the election procedure for the House of Peoples of the Parliamentary Assembly and the Presidency of BH. The European Court of Human Rights(hereinafter: ECtHR) confirmed in this case that passive voting rights of the citizens of $\mathrm{BH}$ who belong to the national minorities have been violated by the constitutional norms which stipulate the structure of aforementioned institutions of $\mathrm{BH}$ (Article IV/1 and V of the Constitution). The ECtHR found the violation of the European Convention and its Protocols in this case, in particular the Protocol 1 and Protocol 12 (see more: Džumhur, 2014: 76).

\footnotetext{
${ }^{1}$ The ECHR; the International Convention on Civil and Political Rights (1966) and the 1966 and 1989 Optional Protocols thereto; the International Convention on the Elimination of All Forms of Racial Discrimination (1965); the Framework Convention for the Protection of National Minorities (1994).

${ }^{2}$ See: The Constitution of BH., Article IV/1 and Article V. Thus, Article IV/1 stipulates: „The House of Peoples shall comprise 15 Delegates, two-thirds from the Federation (including five Croats and five Bosniacs) and one-third from the Republic of Srpska (five Serbs). The designated Croat and Bosniac delegates from the Federation shall be selected, respectively, by the Croat and Bosniac Delegates to the House of Peoples of the Federation. Delegates from the Republic of Srpska shall be selected by the National Assembly of the Republic of Srpska...” In terms of the way of election, the BH Constitution (Article V) stipulates: „The Presidency of Bosnia and Herzegovina shall consist of three members: one Bosniac and one Croat, each directly elected from the territory of the Federation, and one Serb directly elected from the territory of the Republic of Srpska."
} 
Deciding on the filed applications the ECtHR warned that Article 14 of the ECHR has a broader scope of applications in the non-discrimination of the rights and freedoms guaranteed by the ECHR. Therefore, the prohibition of discrimination extends to other rights that are guaranteed by internal law of countries, if those rights are within the framework provided by the ECHR. In this regard, the ECtHR found that Article 3 of the Protocol 1 of the ECHR is applicable in the case of the election of the House of Peoples, regardless of the indirect way of its election procedure. Thereby broad jurisdiction of this House was decisive argument for such a qualification.

The ECtHR also took a stand in terms of the Protocol 12, to which the applicants referred in regard to the restriction of their passive voting right for the Presidency of BH. In fact, by the Article 1 of the Protocol 12 prohibition of discrimination is extended to all the rights guaranteed by the law of the state. In this regard, the ECtHR held that the constitutional provisions that define the structure of the BH Presidency violate the provisions of the Article 1 of the Protocol 12 of the ECHR. It should be emphasized that BH ratified the Protocol 12 and this protocol entered into force on 1 April 2005.

The provisions of the Constitution of BH by which the structure and manner of the election of the BH Presidency and the House of Peoples is stipulated, however, in addition to discrimination against ethnic minorities, which is confirmed by the Sejdić-Finci decision, are also discriminatory to the citizens who belong to the constituent peoples (Raosavljević 2014: 94-100). Thus, Bosniacs and Croats from the RS do not have the right to be candidate neither for the House of Peoples nor for the Presidency of BH, just like the Serbs residing in the other entity - the Federation of BH.

Because of that the new appellation before the ECtHR was submitted in the so called 'Pilav' case. The appellant, Mr Pilav, is a resident of the RS, and as such has no right to be candidate neither for the House of Peoples nor for the BH Presidency. We expect that the ECtHR will make final decision in the Pilav case very soon and that could be a new challenge for the internal political subjects in $\mathrm{BH}$.

The ECtHR also made a ruling in the Zornić case which treats discrimination of BH citizens who do not belong to any of the constituent peoples or ethnic minorities. These are the citizens who link their ethnicity to belonging to the state, i.e. the Bosnians and Herzegovinians. Their political rights to be candidates for the BH Presidency and the House of Peoples have been also violated by the current constitutional provisions.

Thus, the ECtHR rejected the possibility of the partial implementation of ECHR provisions and its Protocols in the case of Sejdić-Finci and the Zornić case. This means that the ECtHR rejected the manner of interpretation of the Constitution of BH in a way which could confirm the concept of a special status of constituent peoples as a legitimate aim with unlimited duration. It means that the constitutional norms that ensure a special status of the constituent peoples must be interpreted in relation to other norms of the BH Constitution, including the Article $\mathrm{III} / 3 \mathrm{~b}$ provision and provisions of the ECHR and its Protocols which were ratified by the state institutions (see: Begić, 2012: 68-69).

Bearing in mind the above mentioned and, in particularly, the fact that the Protocol 12 entered into force on 1 April 2005 BH was obliged, in accordance with international law, but also according to the own Constitution (Article III/3b), to harmonize its legal system with this Protocol after the act of its ratification and entering into force. However, institutions of BH have not implemented these obligations until now, including the Sejdić-Finci decision, and that have caused violating of international law, but also the Constitution of $\mathrm{BH}$, i.e. its Article $\mathrm{III} / 3 \mathrm{~b}$. Because of that, passive voting rights of the national minorities and significant number of the citizens who belong to the constituent peoples as well as passive voting rights of the citizens who do not belong to the constituent peoples nor the national minorities have been violated regardless the fact that $\mathrm{BH}$ have legal obligation to harmonize its Constitution and entire legal system with the democratic standards stipulated by the ECHR and its Protocols. It also brought to a halt BH on its path of European integration in last few years because of, besides the other reasons, non-implementing decision in the Sejdić-Finci case (see more: Pejanović, 2014: 10-11; Krešić, 2014: 84-88).

\section{Perspective of the Stabilization and Association Process}

On June 1, 2015, the Stabilization and Association Agreement entered into force in BH. By signing this Agreement, BH made specific commitments to harmonize its legislation with the EU's.

The key question is: How comfortable is Dayton Constitution in this regard? Does it consist adequate solutions which allow effective progress in regard to conduction reforms stipulated by this and other agreements related to accession to the EU? 
However, the Constitution of BH consists a number of solutions for effective implementation of the obligations under the European integration process. In this regard, Article 1 of the Agreement stipulate the harmonization of BH's legislation with the EU's as one of the priority objectives of the accession, effectively ending the transition to a market economy. Article 70 of the Agreement, which is entirely dedicated to the obligation to implement reforms towards the harmonization of these laws, prescribes the following: "The Parties recognize the importance of harmonizing the existing legislation of $\mathrm{BH}$ with the $\mathrm{EU}$ legislation and its effective implementation. BH will endeavour to ensure the gradual harmonization of their existing laws and future legislation with the legacy of the Union. BH shall ensure the proper implementation and enforcement of existing and future legislation." Paragraph 2 of the same Article establishes the obligation as starting the day of the Agreement signing. In accordance with the same position, BH must extend alignment to all of the EU legacy elements. Further, in accordance with the Agreement, the initial phase of the focus adjustment should be directed to the regulations pertaining to trade and BH's internal market. In the later stages, the emphasis is placed on the remaining parts of the community's legacy.

Thus, the commitments under the Stabilization and Association Agreement are in place to ensure a free and unified market within $\mathrm{BH}$, which is after all a constitutional obligation for all of its institutions (Article $\mathrm{I} / 4$ of the BH Constitution, line 4 of the Preamble). BH is a complex state with complicated decision-making procedures. In addition, the DPA granted the entities most of the important competencies from the European integration standpoint. However, the mutual harmonization of regulations, the adoption of which is the responsibility of the entities, was imposed as a precondition for creating a single market and the BH market economy. In addition, a previous mutual harmonization of entity regulations in the fields that conditioned the existence of a single $\mathrm{BH}$ market was also made a prerequisite for achieving obligations related to harmonizing BH's legal system with EU law. These commitments lead to the necessity of implementing reforms in BH. However, as mentioned before, the DPA granted most of the competencies important to the implementation of the Stabilization and Association Agreement to the entities (RS and Federation of $\mathrm{BH}$ ), creating the possibility that certain domains would be regulated differently. In reality, mutually inconsistent regulations, the adoption of which is the responsibility of the entities, currently exist in the areas most important to the functioning of the single market. In that way there exists inconsistency between entity legislations in almost all fields of property law, commercial law, family etc. as well as civil procedure law matters. This jeopardizes both the principle of the single market and the execution of the commitments under the Stabilization and Association Agreement (see more: Begić, 2012: 69-70; Trnka, 2006: 258-259).

Such a legal situation could be considered unconstitutional in at least two respects. First, it prevents the consistent application of the aforementioned constitutional provisions that impose the obligation of the single market's existence. It also calls into question the implementation of the international law general principle of pacta sunt servanda, to which the $\mathrm{BH}$ Constitution refers in connection with the obligation to perform the contract clauses of the Stabilization and Association Agreement as an international agreement. It is thus important to point out the position of the Constitutional Court on case U-5/98: "Different legal systems of the entities, with different forms of property or property regulation, can actually create a barrier to free movement of goods and capital, which is guaranteed by Article I/4 of the BH Constitution." It is interesting to point out the Constitutional Court's interpretation in subsequent constitutional practices. In case AP-792/06, it took the following view: "The fact that the state must achieve an efficient single market (Article $\mathrm{I} / 4$ of the Constitution of $\mathrm{BH})$ and that the entities regulate certain areas does not automatically mean that the principle of the common market is compromised. In this sense, the state has a wide margin of assessments in terms of organizing a single market within its borders in the most appropriate way ... It is provided by the other constitutional principles, such as the principle of democracy, rule of law and other democratic principles (Article $\mathrm{I} / 2$ of the Constitution of BH). ${ }^{33}$ (see: Alihodžić, Begić, 2013: 345-346)

That the entities are responsible for passing regulations in certain areas should not impede the existence of a single market. Of course, mutually harmonizing these regulations, i.e., the previous obligation arising from the Stabilization and Association Agreement, would achieve the final goal of harmonizing the BH legal system with EU laws.

However, the existence of two parallel and inter-entity non-aligned legal systems with different regulations could jeopardize not only the functioning of the single market in $\mathrm{BH}$, but also the implementation of the Stabilization and Association Agreement, which was previously conditioned upon this Agreement's entry into force. Further, it could ultimately obstruct the European integration process. The previous section refers to the factors that are

\footnotetext{
${ }^{3} \mathrm{http}: / /$ www.ccbh.ba/odluke/?lang=bs\#
} 
directly related to economic status and the liberties on which the market and economy depend (see more: Alihodžić, Begić, 2013: 346-347).

The BH Constitution provides several options for overcoming this situation. This is also an advantage of the Dayton Constitution, which broadly regulates many issues and allows for multiple solutions. The BH Constitution allows flexibility in the division of competencies between the state and entities (see: Begić, 2011: 49-51).

It has adopted the competency distribution model in favour of the entities, specifically including references to state competencies and assigning to the entities all of the other responsibilities. Thus, the competencies of the $\mathrm{BH}$ institutions are established and exhaustively enumerated in Article III/1 of the Constitution. The responsibilities of the $\mathrm{BH}$ institutions include foreign policy; foreign trade policy; customs policy; monetary policy; finances for the institutions and BH's international obligations; immigration, refugee and asylum policies and regulations; international and inter-entity criminal law enforcement, including relations with Interpol; the establishment and operation of common and international communications facilities; and the regulation of inter-entity transportation and air traffic control. However, these are not the only jurisdictions belonging to the state of BH. Article III/5 of the BH Constitution provides for so-called additional state competencies: "BH shall assume the responsibility for such other matters as are agreed by the entities; are provided for in Annexes 5 to 8 of the General Framework Agreement; or are necessary to preserve the sovereignty, territorial integrity, political independence, and international personality of $\mathrm{BH}$. Additional institutions may be established as necessary to

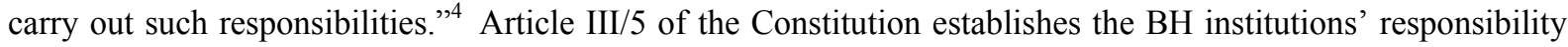
for which entities reach agreements, but also all of the competencies that are necessary to preserve the sovereignty, territorial integrity, political independence and international personality of the state and the matters provided for in Annexes 5-8 of the General Framework Agreement for peace in BH, even if no agreement between the entities related to this. Thus, the conditions for jurisdiction take over by the BH institutions are set not cumulatively but alternatively (see more: Trnka, 2006: 256-257; Begić, 2011: 49-50; Ademović, Marko, Marković, 2012: 109-117; Begić, 2012: 69-70).

Apart from the jurisdictions under Articles III/1 and III/5, there are responsibilities that correspond with the specific competencies of the Presidency and Parliamentary Assembly of BH. The BH Constitution leaves open the possibility that certain entity competencies not taken by the state could be generally regulated by passing laws at the state level without prior redistribution. This practice is confirmed by the decision of the $\mathrm{BH}$ Constitutional Court in case U-5/98. For example, this is generally how the higher education sector is regulated in $\mathrm{BH}$, the responsibility for higher education remains at the level of the entity (RS) or cantons in the FBH (see more: Begić, 2011: 50-51; Ademović, Marko, Marković, 2012: 118-121; Begić, 2012: 71).

Therefore, the specificity of the Constitution precisely consists of a flexible division of responsibilities between the state and entities, and their redistribution is enabled in a way that does not involve amending the Constitution. The takeover of competencies shall technically be carried out by the adoption of appropriate legislation (laws) by the Parliamentary Assembly of BH, which is accompanied by mandatory changes to the Constitution by entities and involves repealing the related entity laws. Thus, although it would be desirable from a legal certainty standpoint, competency redistribution does not necessarily involve changing the BH Constitution. Rather, it implies the adoption of appropriate laws in the Parliamentary Assembly of BH through the regular legislative procedures.

Considering these factors, the obligations of the European integration process to harmonize entity legislation in $\mathrm{BH}$ and $\mathrm{BH}$ laws with EU regulations can be fulfilled in several ways. First, it is possible to transfer competencies from the entities to the $\mathrm{BH}$ institutions in accordance with Article III/5 of the Constitution and the enactment of laws at the state level, at which areas of importance in the European integration process would be uniformly regulated. However, given the current political situation, this solution cannot be considered realistic, as the RS in particular does not want to relinquish its Dayton Constitution-granted jurisdiction.

Another possibility involves adopting the framework law at the state level in accordance with Article IV/4a of the BH Constitution, which determines the basic regulation principles of the areas of importance in the European integration process. In this case, the competency in the subject areas would remain at the entity level. This would include the harmonization of entity regulations in their respective fields with the enacted law, and would thus also imply their mutual harmonization.

\footnotetext{
${ }^{4}$ In this regard see Decision of the Constitutional Court in case U-9/00 (http://www.ccbh.ba/odluke/?lang=bs\#)
} 
The third solution does not involve competency redistribution between the BH institutions and entities or the adoption of any regulations from entity competencies at the state level. Rather, it implies a mutual cooperation of the responsible entity institutions on an approximation of the laws in the important areas of obligation implementation in the European integration process. As such, it would be necessary to use the capacity of the Directorate for European Integration, which was formed at the Council of Ministers, with the aim of mutually harmonizing the relevant areas of European integration. The Directorate for European Integration is responsible for tasks related to the coordination of activities of the $\mathrm{BH}$ authorities that relate to all of the activities necessary for European integration. The Directorate also performs other tasks related to launching initiatives and advises on the harmonization of processes with $\mathrm{BH}$ authority activities to fulfil obligations towards European integration. ${ }^{5}$ This kind of cooperation and coordination could be considered as an constitutional obligation in terms of: 1) the provisions that set the functioning of a free and single market within $\mathrm{BH}$ as a constitutionally defined legitimate goal and 2) the point of execution of the assumed international obligations (see: Alihodžić, Begić, 2013: 346).

\section{Conclusion}

In the post-Dayton period, the opinion prevails that the DPA, including its Annex 4 (the BH Constitution), is not an appropriate framework for the proper implementation of reform processes and accession to the European Union. Such an opinion is based on the objectively complicated organization of BH institutions and the extremely complicated decision making procedures imposed by the DPA. In spite of this, the BH Constitution offers various possibilities for fulfilling those agreed-upon obligations from the European integration process that are related to the harmonization of the $\mathrm{BH}$ and EU legislations and the function of the single market. These are also the obligations specified by the BH Constitution. However, the lack of coordination between the BH Constitution and the European integration process obligations is problematic. What remains important is that pursuant to Article III/3b of the BH Constitution, which refers to the general principle of the international law (pacta sunt servanda), the relevant $\mathrm{BH}$ institutions are obliged to implement reforms that $\mathrm{BH}$ must fulfil according to the international agreements in the European integration process. The international obligations in this process are also the obligations imposed by the BH Constitution itself. As such, the lack of implementation and/or breach of these obligations in turn represent the breach of the BH Constitution. Not with standing all of its disadvantages, the DPA is still a good material for the integration and accession to the European union. It observes stagnation of the European integration path and of $\mathrm{BH}$ reintegration as the consequences of its non-fulfilment, rather than the results of its solutions.

\section{References}

Ademović, N., Marko, J., \& Marković, G. (2012). Constitutional Law of Bosnia and Herzegovina (Ustavno pravo Bosne i Hecegovine). Sarajevo, BH: Fondacija Konrad Adenauer Predstavništvo u Bosni i Hercegovini.

Alihodžić, J., \& Begić, Z. (2013). Legal Preconditions for the Reform of the International Private Law in Bosnia nad Herzegovina (Pravne pretpostavke za reformu međunarodnog privatnog prava u Bosni i Hercegovini). In A. Trgo, \& A. Duraković (Eds.), Legal and Economic Aspects of the Integration of Bosnia and Herzegovina in European Union: Collection of Papers from the International Conference (pp. 335-353). Mostar, BH: University Džemal Bijedić in Mostar.

Basta, K. (2015). Bosnia is not like Yugoslavia: Structure of Frustration and Dinamics of Self-determination in Multiethnic States (Bosna (ni)je poput Jugoslavije: Struktura frustracija i dinamika samoodređenja u multinacionalnim državama). Croatian Political Science Review, 52(1), 163-191.

Begić, Z. (2011). Referendum and its (Miss) Use: Legal Aspect (Referendum i njegova (zlo)upotreba: Pravni aspekt). Sveske za javno pravo, 2(6), 44-55.

Begić, Z. (2012). General Principles of International Law in the Constitutional System of Bosnia and Herzegovina (Opšta načela međunarodnog prava u ustavnom sistemu Bosne i Hercegovine). Anali Pravnog fakulteta u Zenici, 5(9), 53-73.

Begić, Z. (2015). Legality and Legitimacy of the Public Authorities in the Context of the Right to Resist Unjust Government: The Case of Bosnia and Herzegovina (Legalitet i legitimitet državne javne vlasti u kontekstu prava na otpor nepravednoj vlasti: Slučaj Bosne i Hercegovine). In T. Kuzmanić, \& A. Teršek (Eds.),

\footnotetext{
${ }^{5}$ Article 23 (Paragraphs 1and 3) of the Law on the Council of Ministers of Bosnia and Herzegovina, the Official Gazette of BH, 30/03, 42/03, 81/06, 76/07, 81/07, 24/08, 94/07.
} 
Možnosti politike danes (pp. 155-187). Koper, Slovenia: Univerzitetska založba Annales, Univerza na Primorskem.

Begić, Z., \& Idrizović, K. (2015). Elements of Federalism in the Constitutional Organization of Bosnia and Herzegovina. In G. Marković (Ed.), Public Law in Bosnia and Herzegovina: Trends and Challenges (pp. 77-109). Athene, Greece: European Public Law Review and European Public Law Organization.

Besson, S. (2010). Theorizing the Sources of International Law. In S. Besson, \& J. Tasioulas (Eds.), The Philosophy of International Law (pp. 163-187). New York, USA: Oxford University Press.

Cipek, T. (2014). Crisis of Democracy in Bosnia and Herzegovina: Is Direct Democracy Possible Solution? (Kriza demokracije u Bosni i Hercegovini: Je li neposredna demokracija rješenje?). Political Analysis, 5(19), 2-9.

Degan, V. Đ. (2000). International Law (Međunarodno pravo). Rijeka, Cro: Univerzitet u Rijeci.

Degan, V. Đ. (2009). Two Faces of Multiculturalism in Present International Law. In S. Yee, \& J. Y. Morin (Eds.), Multiculturalism and International Law (pp. 517-561). Leiden-Boston, Netherland/USA: Martinus Nijhoff Publishers. http://dx.doi.org/10.1163/ej.9789004174719.i-772.155

Džumhur J. (2014). Non-discrimination - Condition for Achievement of Democracy and Human Rights in Bosnia and Herzegovina (Nediskriminacija - uslov za ostvarenje demokratije i ljudskih prava u $\mathrm{BiH}$ ). In N. Veldžić, \& E. Oruč (Eds.), Bosnia and Herzegovina and Euro-Atlantic Integrations: Current Challenges and Perspectives: Collection of Papers from the International Conference (pp. 73-84). Bihać, BH: University of Bihać. UDK 321.7(497.6).

Filandra, Š. (2014). Bosnia and Herzegovina: Unachieved Uthopy (Bosna i Hercegovina: Neostvarena utopija). Political Analysis, 5(19), 19-24.

Guzman, A. T. (2008). How International Law Works: A Rational Choice Theory. New York: Oxford University Press. http://dx.doi.org/10.1093/acprof:oso/9780195305562.001.0001

Henderson, C. W. (2010). Understanding International Law. West Sussex, UK: Wiley-Blackwell.

Klabbers, J. (2009). Reluctant Grundnormen: Articles 31(3)(c) and 42of the Vienna Convention on the Law of Treatiesand the Fragmentation of International Law. In M. Craven, M. Fitzmaurice, \& M. Vogiatzi (Eds.), Time, History and International law (pp. 141-163). Leiden-Boston, Netherland-USA: Martinus Nijhoff Publishers.

Krešić, T. (2014). European Union and Bosnia and Herzegovina (Europska unija i Bosna i Hercegovina). Adrias, 20, 82-90. UDK 327.39(497.6:4-6EU)

Miéville, C. (2005). Between Equal Rights: A Marxist Theory of International Law. Leiden/Boston: Brill.

Pauwelyn, J. (2003). Conflict of Norms in Public International Law. Cambridge, UK: Cambridge University Press. http://dx.doi.org/10.1017/CBO9780511494550

Pejanović, M. (2014). Ideas for Acceleration of Integration of Bosnia and Herzegovina in European Union (Ideje za ubrzanje integracije Bosne i Hercegovine u Evropsku uniju). In N. Veldžić, \& E. Oruč (Eds.), Bosnia and Herzegovina and Euro-Atlantic Integrations: Current Challenges and Perspectives: Collection of Papers from the International Conference (pp. 5-17). Bihać, BH: University of Bihać. UDK 497.6:061.1EU]339.923.

Pulkowski, D. (2008). Structural Paradigms of International Law.In T. Broude,\& Y. Shany (Eds.), The Shifting Allocation of Authority in International Law Considering Sovereignty, Supremacy and Subsidiarity (pp. 51-79). Oxford-Portland/Oregon: Hart Publishing.

Raosavljević, P. (2014). Protection of National Minorities in Bosnia and Herzegovina in According to International Standards of Human Rights (Zaštita manjina u Bosni i Hercegovini prema međunarodnim standardima ljudskih prava). In N. Veldžić, \& E. Oruč (Eds.), Bosnia and Herzegovina and Euro-Athlantic Integrations - Current Challenges and Perspectives: Collection of Papers from the International Conference (pp. 85-102). Bihać, BH: University of Bihać. UDK 341.234(497.6).

Shaw, M. N. (2003). International Law. Cambridge, UK: Cambridge University Press. http://dx.doi.org/10.1017/CBO9781139051903

Shea, D. R. (1955).The Calvo Clause: A Problem of Inter-American and International Law and Diplomacy. Minneapolis, USA: University of Minnesota Press. 
Simović, N. M., Simović M. (2014). Limits of Competencies of the Constitutional Court of Bosnia and Herzegovina in Constitutionality of Law Proceedings (Granice ovlašćenja Ustavnog suda Bosne i Hercegovine u postupku ocjene saglasnosti Zakona sa Ustavom Bosne i Hercegovine). In M. Lazić, \& I. Pejić (Eds.), Adjustment of the Serbia Law with EU Law: Collection of Papers from the International Conference (pp. 49-71). Niš, Srb.: Faculty of Law, Niš. UDK: 342.565.2(497.6).

Subašić, M. (2015). Bosnia and Herzegovina or Federation of BH and Republic of Srpska - Analysis of the Implementation Possible Consociative and Integrative Approach (Bosna i Hercegovina ili Federacija BiH i Republika Srpska - analiza mogućnosti implementacije konsocijacijskogi integrativnog pristupa). Croatian Political Science Review, 52(2), 61-83.

Trnka, K. (2006). Constitutional Law (Ustavno pravo). Sarajevo, BH: Fakultet za javnu upravu.

Vanjek, D. (2014). Federalism and Constituency of Peoples in Bosnia and Herzegovina: From the Unitary Republic to the Federal State (Federalizam i konstitutivnost naroda u Bosni i Hercegovini: Od unitarne republike do federalne države). Political Analysis, 5(19), 13-20.

Weeramantry, C. G. (2004). Universalising International Law. Leiden-Boston: Martinus Nijhoff Publishers.

Weinert, M. S. (2007). Democratic Sovereignty Authority, Legitimacy, and State, in a Globalizing Age. London, UK: UCL Press.

\section{Copyrights}

Copyright for this article is retained by the author(s), with first publication rights granted to the journal.

This is an open-access article distributed under the terms and conditions of the Creative Commons Attribution license (http://creativecommons.org/licenses/by/3.0/). 